\title{
MONITORING THE CAPABILITY OF PRODUCTION EQUIPMENT IN ORGANIZATION
}

\author{
Miroslav PRÍSTAVKA*, Marián BUJNA \\ Slovak University of Agriculture in Nitra, Slovak Republic
}

\begin{abstract}
This work is focused on determining the capability of production equipment in Volkswagen Slovakia, a.s. during the moulding of a car door. There were taken 150 samples from the moulding process that followed each other. Values were recorded on a Wenzel RAplus 1625 measuring machine. Subsequently, process stability was verified. It showed that measured values had a stable average value, and the process did not show irregularities in the diagrams of the $\bar{X}$ card and s card. After verification of stability, the values of $C_{m}$ and $C_{m k}$ were calculated, which exceeded the minimum requirement of 1.66 and 1.67 , and the requirements for the capability of production equipment have thereby been met.
\end{abstract}

Keywords: capability, organization, quality

Nowadays, organizations must maintain a high level of products quality to be competitive, as today's markets are so open that any poor product would be crowded out by another product in a very short time (Korenko et al., 2010).

Organizations must be able to adapt to market and market and customer requirements because the seller's market is transformed into the buyer's market. If some product, organization or service is perceived and evaluated by buyer as good, he returns again back to producer and conducts a transaction based on a positive experience with quality and price and thus the credibility of buyer against producer is enhanced (Savov et al., 2011).

Proper understanding of requirements moves the organization towards a successful and long-term functioning on the market involving a quality management system. It has been a long time since quality was a privilege and domain of large organizations only because survival on the market is forcing organizations of all sizes to work on the quality management system and implement it in practice (Savov and Lančarič, 2013). The aim of the quality management system is also a long-term maintenance of a stable production process and thus the stability of production quality (Kotorová and Korenko, 2012).

The introduction of the quality management system is the way towards certification ensuring the competitiveness of the organization and its position in the market in terms of the customer. Quality systems are introduced based on the requirements of ISO 9001:2008 (Stasiak-Betlejewska and Borkowski, 2009). The awarded certificate indicates that the system is functional and effective within the organization and based on this, the customer is looking at the organization with greater confidence and certainty that the purchased product or service provided will be of high quality and meet his needs and expectations.

\section{Material and methods}

Nowadays, every organization not only has to maintain the quality of products but also has to strive to constantly increase their quality because of a competitive activity on the market, as market supply is changing from day to day. The implementation of the quality management system is necessary to achieve this objective.

The aim is to verify the capability of the production equipment used to manufacture car doors in Volkswagen Slovakia, a.s. Bratislava (joint stock company).

\section{Selection of checking characters}

Results of evaluation are substantially affected by the right choice of checking characters. When new production equipment is being purchased, each character must have its value expressing the capability of equipment, which must be proved by the subsequent observation. If this is a product with the same types of monitored characters, and its production is performed by the same tool, it is possible to reduce the monitored characters of the same type (Korenko and Kaplík, 2011).

\section{Marginal conditions}

In order to achieve a reliable conclusion, it is always necessary to document the marginal conditions under which the inspection has been performed. Marginal conditions include the details such as machine settings, specific information about the location where the production equipment is operating, and process data.

Machine settings data include:

- speed,

- shift,

- tool,

- cycle,

- cooling emulsion,

- pressures,

- electric current (if the device is intended for welding),

- power,

- changes in optimization measures.

Specific production process data include:

- semi-finished products from various suppliers,

- various ways of pre-processing,

- various production flow, 
- operators change / shift,

- working time of equipment before taking samples for the test.

Marginal conditions characterizing the location of equipment operation include:

- ambient temperature,

- humidity,

- barometric pressure,

- vibration affecting the production equipment,

- location of the production equipment.

\section{Evaluation of measured values}

\section{Examining the patterns of measured values}

The values measured during the inspection are recorded in the evaluation sheet in the order indicated on the product and these values are recorded in a diagram. Before subsequent evaluation, it is necessary to determine whether the values recorded in a card meet the known patterns. If the arrangement of measured values is of a chaotic nature (there are no patterns in this case), the subsequent statistical evaluation is interrupted as the production equipment is incapable. Consequently, it is necessary to take measures leading to improvement of this situation and start a new inspection. Furthermore, it is also necessary to be particular about the fact that the course on the $\bar{X}$ card and $s$ card is continuous and without definable causes. If the course of measured values is subject to normal distribution, it can be stated that the examined process is under control, and we can determine the value of $C_{m}$ and $C_{m k}$.

\section{Stability}

From the production process, a minimum of 50 consecutive products must be selected and divided into subgroups with a minimum size $n=5$. During the test of stability, the average value $\bar{X}_{i}$ and standard deviation $\bar{S}_{i}$ is calculated for each subgroup (Hrubec et al., 2009).

Average value in subgroup:

$$
\bar{X}_{i}=\frac{1}{n} \sum_{j=1}^{n} X_{i j}
$$

for: $i=1,2, \ldots k$ and for $j=1,2, \ldots n$

where:

$$
\begin{array}{ll}
i & - \text { serial number of subgroup } \\
j & - \text { serial number of measured value in subgroup } \\
k & - \text { number of subgroups } \\
n & - \text { subgroup size } \\
X_{i j} & - \text { measured value in the } i \text {-th subgroup }
\end{array}
$$

Standard deviation in subgroup:

$$
s_{i}=\sqrt{\frac{1}{n-1} \sum_{j=1}^{n}\left(X_{i j}-\bar{X}_{i}\right)^{2}}
$$

for: $i=1,2, \ldots k$ and for $j=1,2, \ldots n$

The calculated values $\bar{X}$, and $\bar{s}_{i}$ are recorded in the diagram on the $\bar{X}$ card and $s$ card.
Common average value $\overline{\bar{X}}$ :

$$
\overline{\bar{X}}=\frac{1}{k} \sum_{i=1}^{k} \bar{X}_{i}
$$

Average standard deviation $\bar{s}$ :

$$
\bar{s}=\frac{1}{k} \sum_{i=1}^{k} s_{i}
$$

Determining the limits of stability for $\overline{\bar{X}}$ and $\bar{s}$ Upper intervention limit (HMZ):

$$
H M Z_{\bar{X}}=\overline{\bar{X}}+1.3 \times \bar{s} \geq \bar{X}_{\max }
$$

Lower intervention limit (DMZ):

$$
D M Z_{\bar{X}}=\overline{\bar{X}}-1.3 \times \bar{s} \leq \bar{X}_{\min }
$$

Standard deviation is considered stable if:

$$
H M Z_{s}=2.1 \times \bar{s} \geq s_{\max }
$$

The stability test must be performed to make sure that there are no other effects affecting the process. These effects can be recognized in the diagram of measured values. If mean values and standard deviations are within the limits, it is possible to start the statistical evaluation. However, if these limits are exceeded, it is impossible to continue with further statistical evaluation as this would lead to incorrect results. Then, it is necessary to find disturbing impacts and identify and remove them. If the identified disturbing impacts cannot be removed, the process needs to be transferred to other production equipment or a different manufacturing process should be selected. If the cause is identified and removed, machine capability needs to be reassessed (Egerová et al., 2013).

\section{Calculating the capability indices $C_{m}$ and $C_{m k}$ of equipment}

To determine the machine capability index $C_{m^{\prime}}$ it is necessary to determine the standard deviation of all measured values. Average value of all measured data:

$$
\bar{X}_{N}=\frac{1}{N} \sum_{i=1}^{N} X_{i}
$$

where:

$i=1,2, \ldots N$

$X_{i}-i$-th value of measured character

Standard deviation:

$$
\sigma_{N-1}=\sqrt{\frac{1}{N-1} \sum_{i=1}^{N}\left(X_{i}-\bar{X}_{N}\right)^{2}}
$$

Machine capability index $C_{m}$ :

$$
C_{m}=\frac{U S L-L S L}{6 \times \sigma_{N-1}}=\frac{T}{6 \times \sigma_{N-1}}
$$


where:

USL and $L S L$ - upper and lower specification limits or upper and lower limit value

$T$ - character tolerance

This index provides information on the extent to which the dispersion of measured values uses the permissible tolerance. Evaluation does not consider the location of measured values in the tolerance field; therefore, the $C_{m}$ value can be calculated according to Equation (9) used only for controllable processes (Hrubec et al., 2009).

The minimum requirement for the $C_{m}$ value is:

$$
C_{m} \geq 1.66
$$

The proportion of measuring machine dispersion is included in this limit value, including the uncertainty of setting when determining the measured values. If the value of $C_{m}$ is greater than or equal to 1.66 , it is apparent that machine capability is achieved.

Machine capability index $C_{m k}$ takes into account the position of the value $\bar{X}_{N}$ in the tolerance field:

$$
\begin{gathered}
C_{m k}=\frac{U S L-\bar{X}_{N}}{3 \times \sigma_{N-1}} \\
C_{m k}=\frac{\bar{X}_{N}-L S L}{3 \times \sigma_{N-1}}
\end{gathered}
$$

When evaluating, the number with a lower value from both formulas is used.

The minimum required value for $C_{m k}$ is:

$$
C_{m k} \geq 1.67
$$

The importance of $C_{m k}$ arises with uncontrollable processes such as roughness, shape or position deviation (Hrubec et al., 2009).

\section{Results and discussion}

Volkswagen, a.s. operates in Slovakia for over two decades and brings together the world's leading group brands such as Audi, Porsche, Bentley, Lamborghini, Volkwagen, Škoda, Seat, Bugatti and Scania. Volkswagen Group is the Europe's largest and world's third largest automaker.

\section{Workplace definition}

\section{Machine data:}

Producer: Müller Weingarten AG

Year of production: 2007

Pressure: $39,200 \mathrm{kN}$

Productivity: max. 5,000 pieces per shift

Characteristics: 5-level press

\section{Environment characteristics:}

Air pressure: $1,020 \mathrm{~Pa}$

Humidity: $75 \%$

Operational ambient temperature: $22^{\circ} \mathrm{C}$

\section{Product definition}

The front door of Volkswagen Touareg has been examined. The examined spot is shown in Figure 1. The height of the marked point of coordinate axes origin is being determined.

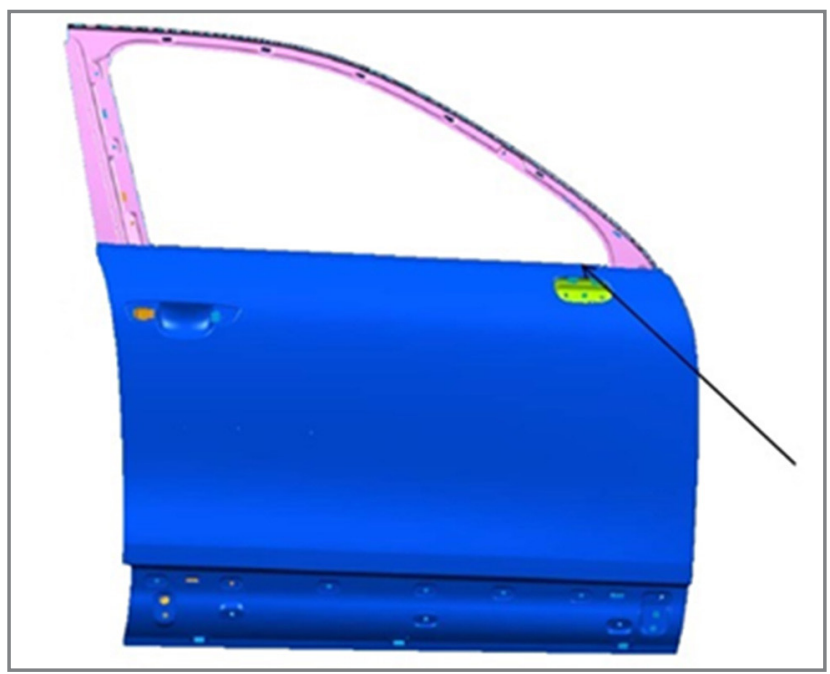

Figure 1 Front door of Volkswagen Touareg

Nominal value in $z$ axis: $774.8_{0.7}^{0.7} \mathrm{~mm}$

Material: sheet HC400LA

Material thickness: $1.2 \mathrm{~mm}$

Number of products: 150

\section{Process description: pressing}

Measurement procedure:

- Inspected product (door) was mounted on the car, the values of which were known in advance.

- Measurements were carried in the appropriate place using the Wenzel RAplus 1625 coordinative measuring machine.

- Data gained were grouped and registered in the relevant document.

\section{Evaluation of measured values}

The data were obtained from 150 samples appropriately labelled as they followed from manufacture. The measured values shown in Table 1 were divided into 15 sub-groups of 10 values.

\section{Stability determination}

Average values of a character in the subgroup and standard deviation were calculated. Subsequently, these values were recorded in the graph of the $\bar{X}$ card and $s$ card.

$$
\begin{aligned}
\bar{X}_{\text {max }} & =774.96 \mathrm{~mm} \\
\bar{X}_{\text {min }} & =774.64 \mathrm{~mm} \\
s_{\text {max }} & =0.358 \mathrm{~mm}
\end{aligned}
$$

Subsequently, the common average value $\overline{\bar{X}}$ and average standard deviation were determined:

$$
\begin{gathered}
\overline{\bar{X}}=744.8333 \mathrm{~mm} \\
\bar{s}=0.2802 \mathrm{~mm}
\end{gathered}
$$


Table 1 Measured values

\begin{tabular}{|l||c|c|c|c|c|c|c|c|c|c|c|c|}
\hline Ser. no. & $x_{1}$ & $x_{2}$ & $x_{3}$ & $x_{4}$ & $x_{5}$ & $x_{6}$ & $x_{7}$ & $x_{8}$ & $x_{9}$ & $x_{10}$ & $\bar{x}_{i}$ & $s_{i}$ \\
\hline \hline $\mathbf{1}$ & 775.2 & 774.8 & 774.9 & 774.4 & 775.1 & 774.6 & 774.9 & 774.5 & 774.9 & 774.8 & 774.81 & 0.251 \\
\hline $\mathbf{2}$ & 774.5 & 775.2 & 774.8 & 774.9 & 774.7 & 775.1 & 775.1 & 775.4 & 774.7 & 774.9 & 774.93 & 0.271 \\
\hline $\mathbf{3}$ & 775.1 & 775.3 & 774.4 & 774.6 & 774.5 & 774.8 & 775 & 774.3 & 774.8 & 774.6 & 774.74 & 0.32 \\
\hline $\mathbf{4}$ & 774.9 & 774.5 & 775 & 774.9 & 775.3 & 775 & 774.7 & 774.9 & 775.2 & 775.1 & 774.95 & 0.233 \\
\hline $\mathbf{5}$ & 774.6 & 774.9 & 774.3 & 774.3 & 774.8 & 775.4 & 774.8 & 774.6 & 775 & 774.7 & 774.74 & 0.327 \\
\hline $\mathbf{6}$ & 774.9 & 775.2 & 774.9 & 775.1 & 774.2 & 774.6 & 774.9 & 775.5 & 774.6 & 774.9 & 774.88 & 0.358 \\
\hline $\mathbf{7}$ & 774.3 & 774.4 & 774.7 & 774.6 & 774.9 & 775.1 & 775.1 & 774.7 & 774.9 & 775.3 & 774.8 & 0.319 \\
\hline $\mathbf{8}$ & 774.6 & 774.9 & 775.1 & 774.9 & 775.3 & 774.6 & 774.4 & 774.9 & 774.6 & 774.7 & 774.8 & 0.27 \\
\hline $\mathbf{9}$ & 774.4 & 774.2 & 774.8 & 774.9 & 774.8 & 774.5 & 774.6 & 774.6 & 775.1 & 774.5 & 774.64 & 0.264 \\
\hline $\mathbf{1 0}$ & 775.1 & 774.9 & 775.2 & 775.2 & 774.5 & 774.9 & 775.3 & 774.9 & 774.6 & 775 & 774.96 & 0.259 \\
\hline $\mathbf{1 1}$ & 774.7 & 775.1 & 774.4 & 774.5 & 775.2 & 774.5 & 774.9 & 774.8 & 774.8 & 774.9 & 774.78 & 0.262 \\
\hline $\mathbf{1 2}$ & 775.3 & 775.1 & 775 & 775.1 & 774.7 & 775.1 & 774.5 & 774.6 & 774.7 & 774.6 & 774.87 & 0.279 \\
\hline $\mathbf{1 3}$ & 775.1 & 774.7 & 774.4 & 775.3 & 774.9 & 774.7 & 775.1 & 775.1 & 774.7 & 775.1 & 774.91 & 0.277 \\
\hline $\mathbf{1 4}$ & 774.7 & 774.9 & 774.8 & 774.4 & 775.1 & 775.3 & 774.7 & 774.8 & 774.9 & 774.8 & 774.84 & 0.241 \\
\hline $\mathbf{1 5}$ & 774.9 & 774.5 & 775.3 & 774.8 & 774.6 & 774.6 & 775.2 & 774.7 & 775.1 & 774.8 & 774.85 & 0.272 \\
\hline
\end{tabular}

\section{Determination of limits}

Those values helped to determine the following values: $H M Z_{\bar{\chi}^{\prime}} D M Z_{\bar{\chi}}$ and $H M Z_{\text {s }}$

$$
\begin{aligned}
H M Z_{\bar{x}} & =775.19 \mathrm{~mm} \geq \bar{X}_{\text {max }} \\
D M Z_{\bar{x}} & =774.47 \mathrm{~mm} \leq \bar{X}_{\text {min }} \\
H M Z_{s} & =0.5922 \mathrm{~mm} \geq s_{\text {max }}
\end{aligned}
$$

As can be seen from the graphs, the curves are continuous, without definable effects. Therefore, the process is stable and we can proceed with calculating the capability index.

\section{Calculating the capability indices $C_{m}$ and $C_{m k}$} After finding the process stable and without definable effects, it was necessary to calculate the value of standard deviation $\sigma_{N-1}$ and the average value of all measurements $\bar{X}_{N}$ :

$$
\begin{aligned}
\bar{X}_{N} & =774.83 \mathrm{~mm} \\
\sigma_{N-1} & =0.08829 \mathrm{~mm}
\end{aligned}
$$

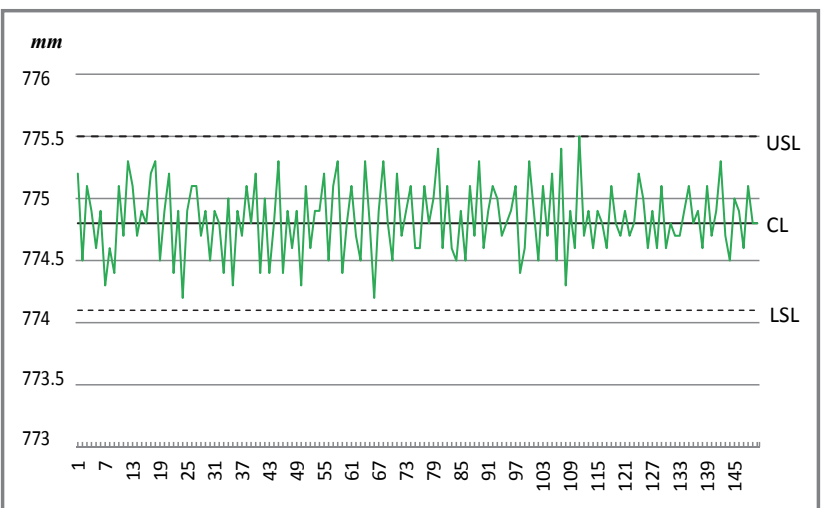

Figure 2 Measured values card

$$
s_{\text {max }}=0.358 \mathrm{~mm}
$$

Capability index $C_{m}$ was subsequently calculated:

$$
C_{m}=2.65
$$

The resulting value of capability index $C_{m}$ clearly shows that 2.65 is higher than 1.66 and thus the requirement on the capability index value is fulfilled.

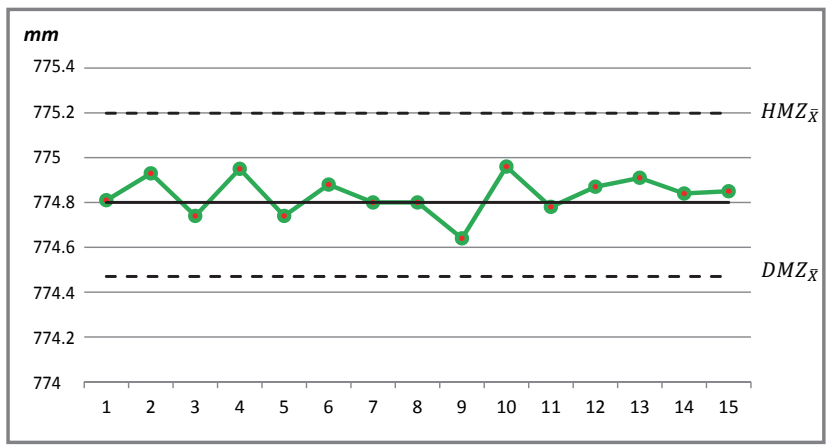

Figure $3 \quad \bar{X}$ card

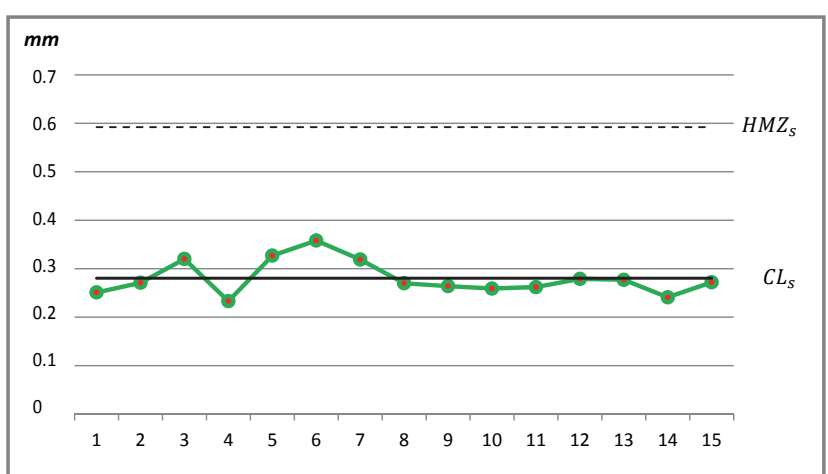

Figure 4 s card 
We needed to calculate the corrected capability index $C_{m k}$. Its value was $C_{m k}=2.53$, meaning that $C_{m k}$ is higher than the prescribed value and the capability of the production equipment was thereby confirmed.

\section{Conclusion}

In the long term, it is necessary that the organization regularly verifies the capability of production equipment, it is competitive on the market and works as efficiently as possible at the lowest cost.

Products that do not meet the requirements of the organization itself rapidly increase the costs of claims and thus reduce the profit of the organization.

The objective was to verify whether pressed pieces made on the press by Müller Weingarten AG are able to meet the requirements for accurate production.

According to the specified methodology, it was necessary to obtain the values that were entered in the appropriate table, of which the graph containing measured values was prepared. Consequently, it was necessary to determine the process stability. The obtained values were recorded in the diagram on the $X$ card and $s$ card. The diagrams indicated that the process is stable and capability index $C_{m}$ and corrected capability index $C_{m k}$ can be determined. Their resulting values proved that the production equipment is capable (Horňák, 2013).

\section{References}

EGEROVÁ, D. - JIŘINCOVÁ, M. - LANČARIČ, D. - SAVOV, R. 2013. Applying the concept of diversity management in organisations in the Czech Republic and the Slovak Republic - a research survey. In Technological and Economic Development of Economy, vol. 19, 2013. no. 2, pp. 350-366.

HORŇÁK, P. 2013. Spôsobilost’ výrobných procesov (bakalárska práca). Nitra : SUA in Nitra, 2013.
HRUBEC, J. - VIRČíKOVÁ, E. 2009. Integrovaný manažérsky systém. Nitra : SUA in Nitra, 2009. ISBN 978-80-552-0231-0.

KORENKO, M. - KAPLÍK, P. 2011. Improvement of process performance and efficiency in a production organisation using a Six Sigma method. In Acta Technologica Agriculturae, vol. 14, 2011. no. 4.

KORENKO, M. - KAPLÍK, P. - BULGAKOV, V. 2010. Implementation of $5 \mathrm{~S}$ approach in the manufacturing organization. In Naukovij visnik Nacionalnogo universitetu bioresursiv i prirodokoristuvanja Ukrajiny, 144, častina 5. Kijiv : Nacionalinyj Univesitet bioresurstv prirodokoritsuvanja Ukrajiny, 2010.

KOTOROVÁ, M. - KORENKO, M. 2012. Využitie štatistických metód v organizácii. In Technika v technológiách agrosektora 2012 : zborník vedeckých prác. Nitra : SUA in Nitra, 2012. pp. 93-97.

PRÍSTAVKA, M. - HRUBEC, J. 2013. Riadenie kvality vo výrobnej organizácii. Nitra : SUA in Nitra, 2013. ISBN 978-80-552-1007-0.

PRÍSTAVKA, M. - BUJNA, M. - KORENKO, M. - KOTOROVÁ, M. ČURGALI, M. 2012. Aplikácia štatistických metód vo výrobnej organizácii. In Kvalita a spolahlivost' technických systémov. Nitra : SUA in Nitra, 2012. pp. 100-102. ISBN 978-80-552-0798-8.

SAVOV, R. - LANČARIČ, D. - PAŠKA, Ĺ. 2011. Strategický manažment kvality $v$ podmienkach agropodnikatelských subjektov na Slovensku. Nitra : SUA in Nitra, 2011. ISBN 978-80-552-0705-6.

SAVOV, R. - LANČARIČ, D. 2013. Manažment podniku. Nitra : SUA in Nitra, 2013. ISBN 978-80-552-1084-1.

STASIAK-BETLEJEWSKA, R. - BORKOWSKI, S. 2009. Controlling w odniesieniu do systemu produkcyjnego. In Cele i uwarunkowania funkcjonowania współczesnych przedsiębiorstw. Gdańsk : Wyd. Wyż.Szk.Bank, 2009. ISBN 978-83-61712-12-1.

\section{Contact address:}

Miroslav Prístavka, Slovak University of Agriculture in Nitra, Faculty of Engineering, Department of Quality and Engineering Technologies, Tr. Andreja Hlinku 2, 94976 Nitra, Slovak Republic, e-mail: miroslav.pristavka@uniag.sk 